\title{
IMPLEMENTASI TRILOGI PENDIDIKAN KI HAJAR DEWANTARA PADA SMK TAMANSISWA DI KOTA TEBING TINGGI
}

Oleh:

Tri Ananda Putri

Mhd. Ihsan Syahaf Nasution

\begin{abstract}
ABSTRAK
Implementasi Trilogi Pendidikan Ki Hajar Dewantara dari perilaku pamong sebagai Ing Ngarso Sung Tuladha terlihat dari keteladanan pamong SMK TI Tamansiswa yang memiliki sikap bertanggung. Perilaku pamong sebagai Ing Madya Mangun Karsa terlihat dari guru memberikan motivasi belajar kepada siswa, memberikan apresiasi dan bersikap sabar serta kekeluargaan. Pamong berperilaku sebagai Tut Wuri Handayani terlihat dari pamong yang mendorong dan mengembangkan kemampuan siswanya untuk berprestasi. Pamong mengimplementasikan tujuan Trilogi Pendidikan dengan cara menciptakan suasana tertib dan damai di lingkungan sekolah dan membentuk siswa yang merdeka mampu berdiri sendiri. Pamong mengimplementasikan prinsip Trilogi Pendidikan dengan cara menerapkan prinsip kebebasan kepada siswa. Pamong mengimplemantasikan fungsi Trilogi Pendidikan dengan cara mengembangkan potensi kodrati anak.
\end{abstract}

Kata Kunci: Implementasi, Trilogi Pendidikan, SMK Tamansiswa 


\section{PENDAHULUAN}

Pendidikan merupakan salah satu kebutuhan pokok bagi kehidupan manusia sehingga dapat menciptakan manusia yang cerdas dan berbudaya serta berkualitas.Ki Hajar Dewantara yang dikenal sebagai bapak pendidikan nasional telah melakukan terobosan baru dalam perjuangan berbangsa dan bernegara.Beliau telah menanamkan jiwa merdeka dan membangkitkan jiwa nasionalisme pada setiap warga bangsa Indonesia. Ki Hajar Dewantara beserta teman-temannya berupaya melakukan pengangkatan derajat bangsa yang terjajah sehingga pada waktu itu dapat berkedudukan sama derajatnya dengan bangsa-bangsa lain di dunia.

Akhirnya sebagai hasil keputusan bahwa bangsa terjajah itu perlu dididik agar mereka memiliki kecakapan, kecerdasan, dan kesadaran untuk bernegara serta jiwa dan semangat kemerdekaan.Ki Hajar Dewantara tokoh nasional yang sangat peduli dengan pendidikan karena jasa-jasanya dibidang pendidikan maka tanggal lahir Ki Hajar Dewantara ditetapkan sebagai hari Pendidikan Nasional.Ki Hajar Dewantara mendirikan Perguruan Tamansiswa pada tanggal 3 Juli 1922 yang pada saat itu Tamansiswa bernama National Onderwys Institut Tamansiswa.

Tamansiswa bukan hanya berkembang pesat di daerah Pulau Jawa, melainkan ke wilayah Sumatera Timur. Awal berdirinya Tamansiswa di Sumatera Timur pada tanggal (15 Agustus 1925) di Galang, kemudian disusul dengan pendirian Tamansiswa di Tebing Tinggi (1 Juli 1928), di Kisaran pada tanggal (1 Juli 1930), Pematang Siantar (3 Juli 1932), Lubuk Pakam (7 Mei 1935) dan Padangsidempuan (3 Juli 1938).

Tamansiswa ini bersama dengan segenap pergerakan kemerdekaan rakyat lainnya berjuang untuk mencapai kemerdekaan bangsa, Tamansiswa dijadikan sebagai tempat untuk menyiapkan tenaga perjuangan kemerdekaan melawan penjajah khususnya di kota Tebing Tinggi. Perguruan Tamansiswa di kota Tebing Tinggi yang berdiri pada tanggal 3 Juli 1928 telah mengelola 6 bagian sekolah yang terdiri dari: taman indria (taman kanak-kanak), taman muda (sekolah dasar), taman dewasa (sekolah lanjutan tingkat pertama), taman madya (sekolah menengah umum), taman 
karya madya ekonomi, (SMK bisnis manajemen), taman karya madya tehnik (SMK teknologi dan industri).

Konsep Pendidikan Ki Hajar Dewantara dilaksanakan menurut "Sistem Among", yaitu suatu sistem yang berjiwa kekeluargaan dan bersendikan dua dasar yaitu, kodrat alam dan kemerdekaan. Pamong sebagai pemimpin proses pendidikan melaksanakan Trilogi Pendidikan yaitu Ing Ngarso Sung Tuladha (di muka memberi teladan), Ing Madya Mangun Karsa (di tengah-tengah membangun semangat), Tut Wuri Handayani (dari belakang memberikan pengaruh/dorongan).

Mencapai hidup tertib dan damai serta membentuk manusia yang merdeka merupakan tujuan dari Trilogi Pendidikan. Menurut paham Tamansiswa masyarakat tertib damai hanya terwujud dalam satu kehidupan bersama berdasarkan cinta kasih sayang antar sesama dalam satu keluarga, yang sama hak dan kewajibannya. Maka dari itu untuk tercapainya tujuan Trilogi Pendidikan ini guru atau pamong harus berusaha untuk dapat mengimplementasikannya kepada peserta didik.

Implementasi Trilogi Pendidikan merupakan proses penerapan ide, konsep atau kebijakan yang dibangun oleh Ki Hajar Dewantara untuk mencapai tujuan pendidikan di Tamansiswa. Begitu juga di SMK Tamansiswa Kota Tebing Tinggi proses implementasi Trilogi Pendidikan dilihat dari proses belajar-mengajar di dalam kelas. Bagi seorang guru/pamong, untuk mengimplentasikan tujuan, prinsip, dan fungsi Trilogi Pendidikan di SMK Tamansiswa Kota Tebing Tinggi, bukan suatu hal yang mudah, harus membutuhkan usaha atau strategi untuk mencapainya.Pencapaian itu dapat terlihat dari materi, kurikulum dan rencana pelaksanaan pembelajaran yang diterapkan di sekolah tersebut. 


\section{PEMBAHASAN}

\section{A. Implementasi Ing Ngarso Sung Tuladha}

Tamansiswa adalah tempat untuk berguru dan bermain.Guru di Tamansiswa namanya pamong.Pamong tugasnya mengasuh, membimbing, jadi sebagai seorang pamong bukan hanya mutlak untuk mengajar saja, tetapi membimbing dan membentuk kepribadian anak dari segi budi pekertinya, dan sopan santun.Keteladanan pamong merupakan karakter yang dimiliki pamong dan dapat memberi contoh serta dapat dijadikan salah satu pijakan bagi siswa untuk melakukan sesuatu.Semua tingkah laku dan sikap yang dilakukan guru sangat berpengaruh terhadap siswa sehingga guru harus menjaga kepercayaan terhadap dirinya.Adapun keteladanan pamong SMK Teknologi dan Industri Tamansiswa Kota Tebing Tinggi yaitu tanggung jawab.

Tanggung jawab merupakan sikap dan prilaku seseorang untuk melaksanakan tugas dan kewajiban yang seharusnya dilakukan.Sikap tanggung jawab tersebut dimiliki pamong dalam menjalankan tugasnya di SMK TI Tamansiswa di Kota Tebing Tinggi.Sikap tanggung jawab pamong tercermin ketika pamong hadir kesekolah dengan tepat waktu, masuk ke kelas sesuai dengan jam yang telah ditentukan.Pamong bertanggung jawab melaksanakan tugasnya seperti membuat prangkat pembelajaran (semester/tahunan), melaksanakan kegiatan belajar mengajar, serta mengadakan pengembangan setiap bidang pengajaran yang menjadi tanggung jawabnya.

Melalui observasi peneliti di SMK TI Tamansiswa Kota Tebing Tinggi bahwa pamong di sekolah tersebut masih berpegang teguh dengan ajaran Ki Hajar Dewantara.Dalam mendidik siswa pamong sebagai Ing Ngarso Sung Tuladha yaitu seorang pemimpin yang didepan memberikan keteladanan yang baik, agar siswa dapat mengikuti keteladanan pamong tersebut. Oleh karena itu pamong di SMK TI Tamansiswa ini mengimplementasikan dengan berbagai cara mereka, tetapi

tidakterlepas dari ajaran Tamansiswa yang menggunakan metode among yaitu kekeluargaan dengan cinta kasih.

Ki Suhartana menjelaskan bahwa adat istiadat di SMK TI Tamansiswa ini adalah ketika pamong masuk ke kelas maka siswa harus mengucapkan salam terlebih 
dahulu kepada pamongnya. Sejalan dengan penjelasan di atas, Nyi Siti Helen menerapkan Ing Ngarso Sung Tuladha dengan cara yang pertama, kalau berbicara kepda siswa penuh dengan sopan santun dan lembut agar siswa dapat mencontoh berbicara kepada temannya yang lain dengan sopan santun juga. Disamping itu siswa dapat menghormati pamongnya.Kedua, tidak memalukan siswa kalau tugasnya tidak siap.Ketiga menghargai siswa yang mengerjakan tugas dengan tepat waktu.

Dari penjelasan di atas peneliti dapat memahami bahwa, implementasi Ing Ngarso Sung Tuladha pamong terhadap siswa sudah baik.Pamong melaksanakan tugasnya dengan baik sesuai dengan apa yang sudah diterapkan disekolah SMK TI Tamansiswa Kota Tebing Tinggi. Sikap Ing Ngarso sung Tuladha pamong memberikan pengaruh terhadap prestasi siswa. pamongmemberikan semangat untuk belajar dan memberikan motivasi kepada para siswa.

\section{B. Implementasi Ing Madya Mangun Karsa}

Ing Madya artinya di tengah-tengah, Mangun berarti membangkitkan atau menggugah dan Karsa diartikan bentuk kemauan atau niat.Maka Ing Madya Mangun Karsa adalah seorang ditengah kesibukannya harus juga mampu membangkitkan atau menggugah semangat.Sama halnya dengan penjelasan yang disampaikan oleh $\mathrm{Ki}$ Suhartana bahwa Madya itu artinya tengah, Ngarsa artinya kerja, jadi Ing Madya Mangun Karsa adalah ditengah-tengah membangun kerja.Implementasi Ing Madya Mangun Karsa pada seorang pamong terlihat ketika pamong berada di tengah-tengah siswa, harus mampu memberikan motivasi agar semua bisa mempersatukan semua prilaku secara serentak untuk mencapai tujuan bersama.

Peran pamong yang menunjukkan perilaku Ing Madya Mangun Karsa adalah dengan memberikan motivasi untuk membangun kehendak bagi siswa. Pamong SMK Tamansiswa di Kota Tebing Tinggi dalam rangka membangun kehendak siswa diimplementasikan dengan: 


\section{Memberikan Motivasi Belajar}

Ki Suhartana sebagai Kepala Sekolah dan mengampu mata pelajaran matematika menerapkan perilaku Ing Madya Mangun Karsa terhadap siswa didalam proses belajar mengajar. Untuk membuat proses pembelajaran yang menarik seorang pamong hendaknya menggunakan metode pembelajaran yang beragam untuk menarik perhatian siswa. Salah satu metode yang sering digunakan pamong adalah diskusi kelompok.Ki Kasdi menjelaskan bahwa metode diskusi kelompok ini merupakan salah satu contoh penerapan dari Ing Madya Mangun Karsa, karena pamong disini sebagai narasumber dan dapat memberikan masukan-masukan serta arahan kepada siswa. Didalam tugas diskusi kelompok dapat membangun karakter siswa untuk bekerja sama, dan bertanggung jawab.

\section{Memberikan Apresiasi Kepada Siswa}

Pamong dapat membangkitkan semangat siswanya dengan cara menghargai hasil pekerjaan dan usaha siswanya dengan memberikan pujian. Bahkan ketika siswa berprestasi tidak jarang siswa diberikan hadiah/reward dan ketika siswa melakukan kesalahan maka dapat diberi hukuman. Nyi Bernalam menjelaskan bahwa jika Nyi Bernalam selalu memberikan semangat kepada siswa, maka siswa akan lebih giat belajar karena merasa diperhatikan pamongnya.

Nyi Bernalam sering memberikan apresiasi kepada siswa yang mengumpulkan tugasnya dengan tepat waktu, dan siswa menjawab pertanyaan yang saya ajukan maka beliau akan memberi tepuk tangan kepada siswa tersebut. Maka dari itu siswa merasa dihargai dan termotivasi untuk mengerjakan soal-soal selanjutnya.Setiap tugas yang dikerjakan oleh siswa di sekolah maupun di rumah, guru (pamong) selalu memberikan tanggapan yang positif kepada siswa.Karena di sini terlihat bahwa siswa tersebut sudah melaksanakan tanggung jawabnya untuk mengerjakan tugasnya.

Seperti sebelum memulai pelajaran Nyi Bernalam meminta siswa memperhatikan kebersihan ruangan kelas, dan siswa tersebutpun bergotong royong membersihkannya. Setelah itu Nyi Bernalam mengucapkan terima kasih kepada siswa, 
karena telah bekarja sama membersihkan ruangan kelasnya sehingga bersih dan nyaman untuk belajar. Peneliti dapat memahami bahwa, apresiasi yang diciptakan oleh kepala sekolah maupun guru menciptakan rasa nyaman kepada siswa di lingkungan sekolah dan mereka merasa dihargai serta diperhatikan.

\section{Pamong Bersikap Sabar Dan Kekeluargaan}

Pamong memberikan layanan yang cukup menarik agar dapat menumbuhkan kepercayaan siswa untuk belajar di SMK TI Tamansiswa Di Kota Tebing Tinggi ini.Seperti metode among yang diterapkan Ki Hajar Dewantara bahwa guru adalah seorang Pamong yang membimbing dan mengarahkan siswanya.Metode ini berjiwa kekeluargaan, hingga hal itu sudah memberi gambaran tentang interaksi yang menjadi antara pamong-siswa.Hubungan antara Pamong-siswa tersebut dilandasi oleh cinta kasih, saling percaya mempercayai, jauh dari sifat otoriter.

Segenap anggota Tamansiswa yang mengabdikan dirinya kepada Sang Anak, hidup bersama-sama dalam satu lingkungan keluarga. Tamansiswa menyebut ikatan hidup ini adalah keluarga suci.Keluarga yang terbentuk oleh kesatuan tekad, oleh satu cita-cita hidup.Bukan keluarga karena pertalian turunan darah, bukan pula karena ikatan daerah dan suku, melainkan keluarga oleh karena sepaham, secita-cita, senasib dan seperjuangan.

Hidup kekeluargaan sebagai sendinya merupakan ciri dari sekolah ini.Hal ini juga dapat dibuktikan dari penjelasan Nyi Sarinah, ketika ada siswa yang melakukan kesalahan seperti terlambat datang kesekolah, maka guru memberikan teguran/hukuman yang wajar bagi siswa yang melanggar peraturan.Seperti meminta siswa tersebut membersihkan lingkungan sekolah. Jadi dengan demikian disamping lingkungan menjadi bersih, siswa tersebutpun terkena efek jera, hukuman lain misalnya Push Up apabila siswa itu cabut, dan yang paling penting adalah nasehat.

Dari penjelasan di atas peneliti dapat memahami bahwa implementasi dari Ing Madya Mangun Karsa terhadap siswa SMK TI Tamansiswa berjalan dengan baik.Guru (pamong) memotivasi siswa dengan memberikan apresiasi dan bersifat sabar serta 
kekeluargaan terhadap siswa serta memberikan motivasi belajar siswa.Dengan adanya motivasi dari guru, mendorong siswa untuk semangat belajar.Pengaruh sikap Ing Madya Mangun karsa oleh guru ini terhadap seluruh siswa yaitu dapat meningkatkan prestasi siswa dan memberikan kesempatan untuk mengembangkan kreatifitas dan bakatnya masing-masing.

\section{Implementasi Tut Wuri Handayani}

Tut Wuri artinya mengikuti dari belakang dan Handayani berarti memberikan dorongan moral atau dorongan semangat. Sehingga artinya Tut Wuri Handayani ialah seseorang harus memberikan dorongan moral dan semangat kerja dari belakang.Seperti yang disampaikan oleh Ki Suhartana bahwa Tut Wuri Handayani mengandung arti mendorong para peserta didik untuk membiasakan diri mencari dan belajar sendiri. Berada di belakang, mengikuti dan mengarahkan anak didik agar berani berjalan di depan dan sanggup bertanggung jawab. Konsep mengenai Tut Wuri Handayani ini bahwa sebagai pemimpin, seorang pamong harus bisa mengarahkan siswa ketika mereka mengalami kesulitan dalam belajar.Lebih lanjut Ki Suhartana menjelaskan bahwa, Tamansiswa itu artinya bebas merdeka, maksudnya merdeka yang bertanggung jawab, jadi ketika pamong memberikan tugas kepada siswa, pamong berusaha untuk membiarkan siswa tersebut mencari jawabannya sendiri, dengan melepaskan mereka

Di dalam dunia pendidikan Ki Hajar Dewantara mempunyai konsep tentang Metode Among.Kata Among berasal dari bahasa Jawa mempunyai arti seorang yang tugasnya "ngemong" atau momong", yang jiwanya penuh pengabdian.Metode tersebut berjiwa kekeluargaan, hingga hal itu sudah memberi gambaran tentang inter-aksi yang terjadi antara pamong-siswa.

Hubungan antara pamong-siswa tersebut dilandasi oleh cinta kasih, saling percaya mempercayai, jauh dari sifat otoriter dan situasi yang memanjakan.Ki Hajar Dewantara menjadikan "Tut Wuri Handayani" sebagai semboyannya Metode Among.Sikap "Tut Wuri Handayani” adalah perilaku pamong yang sifatnya memberi kebebasan kepada siswa, untuk berbuat sesuatu dengan hasrat dan kehendaknya, 
sepanjang hal itu masih sesuai dengan norma-norma yang wajar dan tidak merugikan siapapun.

Tetapi kalau pelaksanaan kebebasan oleh siswa tersebut ternyata menyimpang dari ketentuan yang seharusnya, seperti pelanggar peraturan maka pamong harus bersikap "handayani”.Sikap ini mempunyai maksud untuk menjaga tertib damainya hidup bersama dengan jalan meluruskan kembali perilaku siswa yang tidak lurus tersebut. "Tut Wuri" memberi kebebasan kepada siswa untuk berbuat sekehendak hatinya, namun jika kebebasan tersebut akan menimbulkan kerugian, maka pamong harus memberi peringatan dan sebagainya. "Handayani" merupakan sikap yang harus ditaati oleh siswa, hingga menimbulkan ketertundukan.

Peneliti dapat memahami bahwa, sebagai seorang pamong juga harus menjalankan fungsinya memberikan motivasi dan dorongan moral kepada anak didik untuk terus maju dan berjuang menuntut ilmu. Ajaran Ki Hajar Dewantara sebagai panutan untuk mengembangkan kualitas di SMK Tamansiswa ini.Seperti ajaran “Neng-ning-nung-nang”.Ning dari kata hening yaitu tenang, neng dari kata menang, diam tidak emosi, tidak gegabah, nung dari kata hanung, teguh, kuat, sentosa, dan nang dari kata menang, wewenang. Jadi Siapapun yang tenang akan jernih pikirannya, mudah dapat membedakan barang yang hak dan yang tidak, yang benar dan yang salah, sehingga dia akan menjadi kuat, kokoh dalam kemauannya, kokoh lahir dan batin, untuk mencapai apa yang dikehendakinya, akhirnya dia akan menang, dan berhak atas hasil usahanya.

Sejalan dengan penjelasan di atas, maka perilaku Tut Wuri Handayani juga diterapkan oleh Ki Joko.Beliau mengatakan bahwa, kalau anak itu hobinya menari, maka sebagai pamong harus mengikuti hobinya itu. Dilihat skill anak itu apa, karena ada anak yang mau kesekolah ini, bukan karena pintarnya, tetapi karena bola kakinya, karena dia hobi bola kaki. Jadi setelah tamat nanti mereka punya bekal skill atau kemampuan yang sesuai dengan kemampuannya.Umumnya siswa yang bersekolah di SMK ini sudah mengetahui kalau Tamansiswa lebih unggul dibidang olahraganya. 
Peneliti dapat memahami bahwa orang yang pandai itu harus dari dorongan dirinya sendiri, bukan dari dorongan orang lain, dan seharusnya anak itu pintar bukan karena semata-mata dari pamongnya tetapi karena dia sendiri.Tetapi bukannya pamong tidak berperan, apalagi terkait dengan bakat dan minat anak tadi, seorang pamong harus mampu mengembangkan bakat anak itu terlebih dahulu, barulah berperan sebagai pendorong yaitu perilaku Tut Wuri Handayani.

Implementasi Tut Wuri Handayani berjalan cukup baik. Perkembangan yang menonjol dari siswa dapat dilihat dari prestasi-prestasi yang diraih dari lomba-lomba yang pernah diikutinya. Pamong pun diberi kesempatan untuk mengembangkan kemampuannya dengan tugas-tugas yang sudah ditentukan.Pengaruh dari Tut Wuri Handayani yaitu dapat mengembangkan kemampuan dan karier secara optimal sehingga mutu layanan lebih baik.

\section{Pamong Menciptakan Suasana Tertib dan Damai}

Manusia merdeka lahir dan batin yang dikehendaki adalah individu yang merdeka perasaannya, dan merdeka perbuatannya.Tertib dan damai sebagai tujuan merupakan salah satu pergaulan hidup yang tertib dan teratur, tidak hanya dari fisiknya saja yang tenang dan tertib sedangkan jiwanya tertekan pada kebebasan tetapi tata dan tertib dengan sukarela, tentram dan damai.

Tujuan Ki Hajar Dewantara mendirikan Tamansiswa ini untuk membentuk masyarakat Indonesia keluar dari kebodohan.Seperti yang disampaikan oleh $\mathrm{Ki}$ Suhartana bahwa, Tamansiswa didirikan sebelum Indonesia merdeka. Beliau berfikir rakyat Indonesia ini tidak boleh bodoh, dengan demikian Ki Hajar mendirikan sekolah supaya orang-orang yang tidak punya kesempatan mengenyam pendidikan di Hindia Belanda juga bisa mendapatkan pendidikan, karena pada waktu itu zaman penjajahan tidak semua warga pribumi boleh sekolah, maka Ki Hajar mendirikan sekolah yang bercirikan kebangsaan sesuai dengan jiwa dan semangat nasionalisme Ki Hajar, maka dia membuat semboyan dengan etos kerja, lawan sastra ngesti mulyo, maksudnya hanya dengan ilmu pengetahuan semua orang akan mencapai kemuliaan. 
Pengertian tertib dan damai menurut ajaran Ki Hajar Dewantara adalah tertib yang tidak mengganggu kedamaian orang lain, jadi sebetulnya yang namanya tertib dan damai itu dia disiplin tapi timbul dari dalam dirinya, kalau siswa hanya diam di dalam kelas karena takut dengan pamong itu sebetulnya bisa dikatakan tertib juga, tetapi tidak bisa dikatakan damai. Menciptakan tertib damai itu adalah bagaimana di kelas itu menjadi tertib dan hati tetap nyaman.

Penerapan tujuan trilogi pendidikan Ki Hajar Dewantara oleh pamong kepada siswanya di sekolah ini memiliki caranya masing-masing, kalau Nyi Bernalam menciptakan suasana tertib dan damai dilakukan dengan terlebih dahulu membuat kelas nyaman.Selain itu tujuan trilogi pendidikan Ki Hajar Dewantara ini dapat diimplementasikan melalui pendidikan di keluarga, sekolah dan masyarakat.Pendidikan yang paling utama itu adalah di keluarga, setelah itu sekolah, dan barulah di masyarakat.Peran orang tua terhadap anak itu sangat dibutuhkan agar anak memiliki kepribadian yang baik.Jadi pendidikan itu tidak hanya diterapkan di sekolah saja, tetapi harus sinkron antara pendidikan di rumah dan di sekolah.

Peneliti dapat memahami bahwa, susana tertib dan damai sebagai tujuan Trilogi Pendidikan Ki Hajar Dewantara merupakan salah satu hal yang sangat penting diterapkan pamong di lingkungan belajar agar tercapainya ketenangan dan keteraturan. Menurut paham Tamansiswa tertib dan damai hanya terwujud dalam satu kehidupan bersama berdasarkan cinta dan kasih sayang antar sesama dalam satu keluarga, yangsama hak dan kewajiban, sama derajat dan martabatnya merasakan kemanusiaan, sama merata merasakan rejeki kemurahan Tuhan.

\section{Membentuk Siswa yang Merdeka (Mampu Berdiri Sendiri)}

Membentuk siswa merdeka lahir batin melalui pendidikan, diharapkam para tamatan SMK Tamansiswa harus mampu hidup disiplin, mampu berpikir dan berbuat positif, dan mampu menggunakan hak asasinya seimbang dengan kewajiban asasinya. Oleh karena itu guru sebagai tenaga pendidik harus mampu mewujudkan tujuan tersebut.Untuk menggambarkan sistem pendidikan seperti yang dicita-citakan 
Tamansiswa, yang gagasan aslinya merupakan cetusan Ki Hajar Dewantara, maka sistem itu lebih tepat dilambangkan dengan among, dan para petugas pelaksana pendidikan Among itu di sebut Pamong.

Pamong bukan sekedar menyajikan ilmu dan pengetahuan sebagai mana dipedomani oleh kurikulum saja.Hal ini memang cukup penting namun bukan hanya itu saja. Dengan asas kemerdekaan itu ditimbulkan dan dikembangkan oto-aktivitas anak didik., agar berkembang kreativitasnya, dan dengan cara kreatif anak didik mampu mencari sendiri pengetahuan yang mereka perlukan. Setelah pengetahuan itu benar-benar dikuasai oleh anak didik, hendaknya dapat dimanfaatkan bagi kepentingan hidup bersama.Artinya dengan ilmu pengetahuan yang dimiliki, anak didik itu dapat hidup dan kehidupannya bermanfaat bagi masyarakatnya.

Seperti guru di SMK Tamansiswa Jurusan Teknik Sepeda Motor mereka tidak hanya memberikan materi pembelajaran saja yang sesuai dengan kurikulum kepada siswa, tetapi juga menanamkan motivasi belajar untuk siswa.Misalnya motivasi untuk disiplin.Pamong sebagai pembimbing yang mengayomi siswa agar menjadi seseorang yang berkualitas, baik dari segi akademik maupun budi pekertinya.

Ki Suhartana mengatakan tujuan Tamansiswa untuk mendidik manusia merdeka, tujuannya itu sifatnya merdeka, lahir dan batin, salam tertib dan damai, salam dan bahagia, jadi merdeka tadi adalah tidak mengganggu kemerdekaan orang lain. Sebenarnya pengertian dari kebebasan yang tidak menggangu kebebasan orang lain, yaitu merdeka yang bertanggung jawab, itu artinya kebebasan yang bertanggung jawab jadikan tidak sebebas bebasnya. Bebas yang tidak ada batasnya, bukan bebas yang dibatasi oleh kebebasan orang lain, ketika kita ingin melakukan sesuatu sesuai dengan kehendak kita maka ingat, kalau kehendak kita itu juga dibatasi oleh kehendak orang lain.

Sejalan dengan penjelasan di atas maka Ki Joko juga menjelaskan bahwa, anakanak Tamansiswa datang ke SMK ini dari yang tidak tau apa-apa, dibina menjadi bermanfaat.Bahkan ada semboyan, anak Tamansiswa ada di mana-mana tetapi tidak kemana-mana. Misalnya ada di kantor lurah, pajak, supir, guru, polisi, camat. 
Maksudnya siswa Tamansiswa ini dia mandiri, oleh sebab itu pamong mendidik siswa untuk mandiri.Seperti yang kita lihat bahwa anak-anak Tamansiswa itu kebal, dan tidak malu-malu.

Peneliti dapat memahami bahwa untuk membentuk siswa SMK Tamansiswa yang merdeka atau dapat berdiri sendiri pamong harus mampu disiplin, pada diri sendiri yang berdasarkan nilai hidup yang tinggi.Dan seorang pamong harus bisa menciptakan suasana yang membuat siswa aktif bertanya serta mengemukakan pendapatnya sendiri. Jadi siswa mampu menghasilkan sesuatu untuk kepentingan dirinya dan orang lain. Selain itu pamong membuat perubahan dalam proses pembelajaran dengan menggunakan berbagai metode, sehingga siswa merasa nyaman dalam belajar.

\section{Pamong Menerapkan Prinsip Kebebasan}

Pamong SMK Tamansiswa Kota Tebing Tinggi memberikan kebebasan kepada peserta didik untuk membuat keputusan sesuai dengan hasrat dan kehendaknya, sepanjang hal itu masih sesuai dengan norma-norma yang wajar dan tidak merugikan dari ketentuan yang seharusnya, seperti melanggar peraturan yang berlaku dan bisa merugikan pihak lain atau diri sendiri.

Dengan demikian kebebasan diri juga berarti dapat memelihara kebebasan orang lain, tidak menyusahkan atau merepotkan orang lain. Batas kebebasan itu diatur oleh norma-norma masyarakat, nilai peraturan-peraturan dan hukum yang berlaku wajib ditaati.Hal ini berarti manusia bebas harus dapat mengendalikan diri, dan mengatur diri sendiri secara disiplin mematuhi segala peraturan.Prinsip ini sesuai dengan konsep Tut Wuri Handayani.Pamong berupaya untuk memberi kebebasan kepada siswa dalam melakukan berbagai aktifitas sesuai dengan apa yang mereka inginkan. Selain itu pamong menciptakan kondisi siswa agar merasa aman untuk melakukan aktifitas di dalam lingkungan sekolah.

Peneliti dapat memahami bahwa penerapan prinsip kebebasan yang dilakukan oleh Ki Joko dapat melatih siswa belajar bahwa ketika mereka telah membuat suatu 
peraturan kelas, maka mereka memiliki tanggung jawab sosial untuk mentaati peraturan tersebut dengan segala konsekuensinya.Kalau dalam segi pelajaran Ki Joko membuat diskusi kelompok, mendorong siswa untuk mengkomunikasikan pemahaman mereka terhadap permasalahan yang dibahas.Ada siswa yang menjadi moderator yang memimpin jalannya diskusi. Setelah itu ada proses tanya jawab, dan siswa berhak mengeluarkan pendapatnya. Selanjutnya beliau memberikan apresiasi kepada jawaban siswa tersebut, sejauh jawaban tersebut sesuai dengan logika.

Sejalan dengan penjelasan di atas, maka Ki Kasdi juga mengatakan bahwa, prinsip kebebasan yang dimaksud bukan bebas yang tidak teratur.Bebas disini maksudnya para siswa bebas untuk berkreatifitas.Jadi kalau ada anak-anak yang bakatnya keolahraga, teater, membaca puisi, dan yang lainnya maka sebagai seorang pamong tidak boleh melarang mereka.Jadi siswa terserah menentukan sendiri tetapi tidak boleh lepas dari pengawasan pamong, tetap harus ada pembinaan. Selain itu dari mulai pendaftaran pihak sekolah sudah menjaring atau mengrekrut anak-anak yang bisa dibidang olahraga.Seperti disyarat pendaftaran bagi anak-anak yang mempunyai sertifikat kejuaraan olahraga, bisa lampirkan. Dan anak-anak tersebut akan diberikan baju olahraga gratis, hal ini salah satu daya tarik untuk siswa yang ingin bersekolah di SMK Tamansiswa ini.

Kebebasan yang diberikan guru kepada siswa berguna untuk mengembangkan potensi yang ada didalam dirinya.Bagi siswa yang memiliki bakat dibidang seni seperti bernyanyi atau teater terus dibimbing guru agar mereka terlatih dan dapat diperlombakan.Guru-guru di SMK Tamansiswa membentuk kelas yang sesuai dengan bakat masing-masing siswa.Seperti ada kelas teater dan bernyanyi. Jadi bagi anak-anak yang minatnya bernyanyi, akan digabungkan dalam satu tinnya yaitu kelas bernyanyi, begitu juga dengan teater. Sama halnya dengan anak-anak yang memiliki bakat bola kaki dan volly, mereka dilatih dalam tiap-tiap timnya.

Sejalan dengan penjelasan di atas, Ki Joko juga menjelaskan bahwa di SMK Tamansiswa ini ada penjaringan atau pengrekrutan terhadap anak-anak yang mempunyai bakat tersebut.Misalnya ketika ada pertandingan olahraga guru-guru ikut 
untuk memonitor. Guru olahraga melihat anak-anak SMP yang memiliki kemampuan bermain bola itu dari sekolah mana, dan setelah itu diadakan pendekatan. Guru bercerita kepada siswa tersebut dan mengatakan kalau dia bermain bolanya bagus. Nanti kalau melanjutkan sekolah, masuklah ke SMK Tamansiswa karena di sekolah ini banyak bantuan-bantuan untuk siswa, misalnya meringankan uang sekolah.Selain itu di sekolah ini untuk baju praktek olahraga dikasi gratis.Oleh karena itu banyak anakanak yang mempunyai bakat olahraga bersekolah di SMK Tamansiswa ini.

\section{Guru Mengembangkan Potensi Kodrati Anak}

Ki Suhartana menjelaskan bahwa, Tamansiswa itu mempunyai dasar, yaitu panca darma.Panca artinya 5, dan darma itu artinya pengabdian, terutama itu kodrat alam.Kodrat alam kalau diidentikkan dengan Pancasila yaitu sila pertama, Ketuhanan Yang Maha Esa. Sebetulnya setiap manusia itu sudah digariskan oleh yang Maha Kuasa sesuai dengan kehendakNya, jadi kalau kita sebagai pamong, sebagai orang tua, sebagai pendidik, dalam hal mendidik anak memang tidak bisa anak itu dituntut seperti kemauan kita karena secara kodrati, secara alamiah, secara garis ketuhanan dia itu sudah memiliki ciri-ciri seperti itu, itulah kita tidak bisa memaksakan kehendak mereka.

Peneliti dapat memahami bahwa, siswa yang ada di SMK TI Tamansiswa Tebing Tinggi merupakan siswa yang memiliki kemampuan berfikir yang berbedabeda.Ada anak-anak yang pintarnya dibidang olahraga, dan ada yang baik dibidang akademiknya.Jadi sebagai pamong harus pandai membaca karakter setiap siswanya.Dengan membimbing, melatih dan mengarahkan bakat si anak supaya tumbuh dan berkembang dan menjadi orang yang terkemuka.Seperti metode among, jadi seorang pamong harus bisa membimbing siswanya sepenuh hati. Harus dapat mengeluarkan kemampuan siswa agar menjadi siswa yang terampil. 


\section{PENUTUP}

Implementasi trilogi pendidikan merupakan proses penerapan ide, konsep atau kebijakan yang dibangun oleh Ki Hajar Dewantara untuk mencapai tujuan pendidikan di Perguruan Tamansiswa, yang digunakan sebagai pijakan dalam trilogi pendidikan di Perguruan Tamansiswa yakni Ing Ngarso Sung Tuladha, Ing Madya Mangun Karsa, Tut Wuri Handayani. Ing Ngarso Sung Tuladha bahwa seorang guru/pamong hakikatnya harus bisa berprilaku di depan seorang pendidik harus memberi teladan atau contoh tindakan yang baik kepada peserta didiknya, maka ia merupakan tokoh panutan, memberikan apresiasi kepada siswa, pamong bersikap sabar dan kekeluargaan, dan memberikan motivasi belajar, serta memberikan dorongan moral atau dorongan semangat kepada siswa.

Implementasi tujuan trilogi pendidikan Ki Hajar Dewantara di SMK TI Tamansiswa Kota Tebing Tinggi yang pertama diimplementasikan dengan pamong menciptakan suasana tertib dan damai di lingkungan belajar dan membentuk siswa merdeka lahir batin.Implementasi prinsip trilogi pendidikan Ki Hajar Dewantara di SMK TI Tamansiswa Kota Tebing Tinggi, diimplementasikan melalui prinsip kebebasan.Pamong memberikan kebebasan kepada peserta didik untuk membuat keputusan sesuai dengan hasrat dan kehendaknya, sepanjang hal itu masih sesuai dengan norma-norma yang wajar dan tidak merugikan dari ketentuan yang seharusnya.Implementasi fungsi trilogi Ki Hajar Dewantara di SMK TI Tamansiswa Kota Tebing Tinggi diimplementasikan melalui pengembangan potensi kodrati anak.Pamong harus mengamati agar anak-anak tumbuh menurut kodratnya.Setiap anak pasti mempunyai potensi yang tertanam pada masing-masing individu yang digali untuk dapat dikembangkan. 


\section{REFERENSI}

Ardi, Muhammad. (2004). Profile perguruan Tamansiswa Cabang Tebing Tinggi 1928-2004. Tebing Tinggi: Perguruan Tamansiswa Cabang Tebing Tinggi.

Armayani, Yesi. (2014). Peranan Perguruan Taman Siswa terhadap Pendidikan di Kota Kisaran KabupatenAsahan (1930-2013). (dalam Skripsi Jurusan Sejarah Fakultas Ilmu Sosial UNIMED).

Jassin, H.B. (1995). Demokrasi Dan Kepemimpinan (Kebangkitan Gerakan Tamansiswa). Jakarta: Balai Pustaka.

Kriswianti Nugrahaningsih, Theresia. (2011). Implementasi Ajaran Ki Hajar Dewantara Dalam Pembelajaran Matematika Untuk Membangun Karakter Siswa. (dalam Seminar Nasional Matematika Dengan Tema” Matematika Dan Pendidikan Karakter Dalam Pembelajaran" Pada Tanggal 3 Desember 2011 Di Jurusan Pendidikan Matematika FMIPA UNY), ISBN : 978-979-163536-3.

Kuntowijoyo. (1995). Pengantar Ilmu Sejarah. Yogyakarta:Bentang Pustaka.

Nasution, Farizal. (2012). Tebingtinggi Tempo Doeloe. Tebing Tinggi: Mitra

Sadulloh, Uyoh. (2008). Pengantar Filsafat Pendidikan. Bandung: Penerbit Alfabeta.

Sevilla, G. Consuelo. (2006). Pengantar Metode Penelitian. Jakarta: UI-Press.

Suparti, Wenti. (2013). Implementasi Trilogi Ki Hajar Dewantara Dalam Kepemimpinan Kepala Sekolah Di SMA Taman Madya Ibu Pawiyatan Yogyakarta. (dalam Skripsi Jurusan Kependidikan Islam Fakultas Ilmu Tarbiyah dan Keguruan Universitas Islam Negeri Sunan Kalijaga).

Suratman.(1992). Pendidikan Dan Pengembangan Sumber Daya Manusia (Peringatan 70 Tahun Tamansiswa). Yogyakarta: Majelis Luhur Persatuan Tamansiswa. (1982). 60 Tahun Taman Siswa (1922-1982). Yogyakarta: Percetakan Tamaln Siswa.

Surjomihardjo, Adurachman. (1986). Ki Hajar Dewantara Dan Tamansiswa Dalam Sejarah Indonesia Modren. Yogyakarta: Sinar Harapan.

Tauchid, Moch. (1976). Pendidikan dan Pembangunan. Yogyakarta: Majelis Luhur Tamansiswa. 